\title{
Factors Affecting Impulse Buying In Alfamart Customers In Ujungberung Sub-District, Bandung
}

\author{
Rita Aryani \\ Department of Business Administration Padjadjaran University, \\ Bandung, Indonesia \\ Ria Arifianti \\ Department of Business Administration Padjadjaran University, \\ Bandung, Indonesia \\ Suryanto \\ Department of Business Administration Padjadjaran University, \\ Bandung, Indonesia \\ Margo Purnomo \\ Department of Business Administration Padjadjaran University, \\ Bandung, Indonesia
}

\begin{abstract}
Consumer behavior that draws in the behavior of the modern retail is impulse buying or commonly known as marketers with unplanned purchase. Impulse buying is part of a condition called unplanned buying or an unplanned purchase that is more or less happened to be different with the consumer's spending plan. Type of the research is field research. This study uses the data obtained from field studies by ways of observing, recording and collecting various information and data found in the field through case studies and surveys. Based on the research, the most dominant factor affecting impulse buying is spontaneous decision factor. Based on the results of descriptive statistics, spontaneous decision factor is characterized by a feeling of excitement and feeling of spirit.
\end{abstract}

Keywords: impulse buying, unplanned purchase.

\section{INTRODUCTION}

According to Utami (2010: 67) impulse buying or unplanned purchases are another form of consumer buying patterns. In accordance with its terms, the purchase is not specifically planned. Imaginary purchase occurs when the consumer suddenly experiences a strong and firm desire to buy immediately. This is due to several factors such as, emotions or moods, attractive prices, the response of the shopping environment, the perceived promotions of profit, and the high level of income. So it stimulates consumers to make unplanned purchases or impulse buying.

Ujungberung is a sub-district located in east Bandung, it has 661,258 Ha, consists of 5 urban villages, 58 hamlets, and 305 neighbourhoods. Ujungberung is an area of residential development with 64.654 population based on population data in December 2017. Along with the rapid development of population in Ujungberung, impacts on the development of retail business, where retail stores that is quite prominent in Ujungberung sub-district are Indomart, Alfamart and SB mart. Indomart, Alfamart and SBmart in Ujungberung are retail businesses 
directly related to the final consumer with the aim to serve what consumer needs, namely an integrated shopping place that sells goods from daily necessities to various types of goods with volume transactions either small, medium and large. The goods are diverse, such as kitchen items, home furnishings, bathroom furniture, cosmetics, accessories and others so it may known as Minimarkets. Minimarket is also one of the modern retailers who feel the impulse buying made by customers in buying daily needs. This can be seen in table 1.1 below:

Table 1.1

Recapitulation of Minimarket Sales Turnover in Ujungberung Year 2017

\begin{tabular}{|c|l|c|}
\hline No. & \multicolumn{1}{|c|}{ Retails } & Sales Turnover \\
\hline 1 & Indomart & Rp. 1.033 .972 .320 \\
\hline 2 & Alfamart & Rp. 1.840 .820 .300 \\
\hline 3 & SB Mart & Rp. 1.325 .683 .800 \\
\hline
\end{tabular}

Source: Economic Section of Ujungberung, Bandung, Year 2018

Based on sales turnover data for the past 1 year (January through December 2017) above, the very fundamental difference of the three existing retail stores in Ujungberung indicates strong competition, and the optimal marketing strategy needed to increase sales turnover. In addition, the knowledge about consumer behavior in making purchases and also consumer desires are needed for marketers and essential for the survival of this retail business. This is the foundation of this research, that is to examine consumer behavior in Ujungberung which has characteristics in terms of making an unplanned purchase or impulse buying. However, this study only limit one minimarket in Ujungberung area, Alfamart.

\section{RESEARCH METHODS}

This study uses marketing management science approach. In addition, this research approach uses descriptive methods. Descriptive research conducted in this study aims to create a description or description systematically, factually and accurately about the facts about impulse buying. This research uses questioner as main data collection tool. (Aaker, Kumar, Day, 2004: 75-77). The type of this research is a field research, meaning the data that obtained from field research by observing, recording and collecting various information and data found in the field through case studies and surveys. In order to collect various information needed in this research, questionnaires used in direct visits to the research site, Alfamart in Ujungberung.

\section{RESULTS AND DISCUSSION}

Description of the variables category describes the responses of respondents regarding the behavior of impulse buying on minimarket Alfamart customers in Ujungberung, Bandung. The results of research data that has been obtained then categorized into five groups of categories with the formula that has been determined in determining the level. Data analysis is as follows:

\section{Spontaneus Decision}

Spontaneous decision is a decision that arises because the emergence of the problems that occur suddenly. The process or stage of purchasing decisions occurs when a consumer recognizes an insatiable need. Understanding the types of consumer decisions will make it easier for marketers to identify the needs of consumers. There are three types of consumer decision making processes such as, broad problem solving, limited problem solving, and custom decision making processes (Utami, 2006: 36).

Based on interviews one of the informants. obtained information that during this spontaneous decisions arising from consumers if observed further is because if they are longer inside the store, this could increase the opportunity for spontaneous purchases. Because the decision making process to make a purchase can be done in the store, it's important for us to provide 
convenience to consumers inside the store because it can affect the process of spontaneous purchasing decision. While the results of descriptive analysis for the dimensions of spontaneous decision factors obtained the minimum value of which can be seen from the table as follows:

Table 1.2.

Spontaneous Decision Factors Affecting Impulse Buying

\begin{tabular}{|l|c|c|c|c|c|c|c|}
\hline \multicolumn{1}{|c|}{ Factors } & $\mathbf{5}$ & $\mathbf{4}$ & $\mathbf{3}$ & $\mathbf{2}$ & $\mathbf{1}$ & Score & Average \\
\hline $\begin{array}{l}\text { When I see a product that I really } \\
\text { want, I'll buy it sooner even though } \\
\text { I have not planned to buy it yet }\end{array}$ & 14 & 36 & 27 & 12 & 11 & 330 & 3,30 \\
\hline $\begin{array}{l}\text { I bought the product I first saw } \\
\text { spontaneously }\end{array}$ & 18 & 12 & 39 & 22 & 9 & 308 & 3,08 \\
\hline $\begin{array}{l}\text { The existence of spontaneity when } \\
\text { I see the product in the } \\
\text { supermarket to have }\end{array}$ & 13 & 25 & 39 & 12 & 11 & 317 & 3,17 \\
\hline Total & & & & & $\mathbf{9 5 5}$ & $\mathbf{9 , 5 5}$ \\
\hline
\end{tabular}

Source: Research Results, 2018

Spontaneous decision factor based on consumer perception is in high category, or in other words Alfamart consumer in Ujungberung, Bandung always tend to make spontaneous purchasing of goods offered by retailers. From the table shows that the respondents who rated the impulse buying variable is in the high category by $11.65 \%$. This result is in line with the theory put forward by Rook in Cahyorini and Rusfian (2011), that impulsive purchases occur unexpectedly and motivate consumers to buy as well, often because of the response to visual point of sale stimulus.

\section{Reflect Decision}

Consumer reflex decisions are one of the factors that may occur impulsive buying behavior. In order to fulfill the daily needs, a consumer must choose the products and/or services to be consumed. The number of options available, the conditions at hand, and the underlying considerations will make the decision of one individual different from the other. From the results of interviews with one of the sources in this research, obtained information that Alfamart customers in Ujungberung, Bandung tend to have a fairly reflective behavior, that is when consumers see a certain item on display retailers, they immediately make decision to buy directly without any consideration first. The result of descriptive analysis for the dimension of reflection decision factors obtained minimum value which can be seen from the table as follows:

Table 1.3.

Reflect Decisions Factors Affecting Impulse Buying

\begin{tabular}{|l|c|c|c|c|c|c|c|}
\hline \multicolumn{1}{|c|}{ Factors } & $\mathbf{5}$ & $\mathbf{4}$ & $\mathbf{3}$ & $\mathbf{2}$ & $\mathbf{1}$ & Score & Average \\
\hline $\begin{array}{l}\text { When I see something really } \\
\text { interesting to me, I will buy it } \\
\text { without considering the } \\
\text { consequences }\end{array}$ & 14 & 36 & 27 & 12 & 11 & 330 & 3,30 \\
\hline $\begin{array}{l}\text { I will think over and over before } \\
\text { deciding to buy a product }\end{array}$ & 18 & 12 & 39 & 22 & 9 & 308 & 3,08 \\
\hline $\begin{array}{l}\text { I will still buy products that I find } \\
\text { interesting even if they do not } \\
\text { need them }\end{array}$ & 13 & 25 & 39 & 12 & 11 & 317 & 3,17 \\
\hline Total & & & & $\mathbf{9 5 5}$ & $\mathbf{9 , 5 5}$ \\
\hline
\end{tabular}

Source: Research Results, 2018 
Reflect decision factors based on consumer perception is in medium category, or in other hand, Alfamart consumer in Ujungberung, Bandung, when going to shop a product of goods that exist in retail outlet always make first consideration of goods to be purchased. In addition, this is also caused, when a new consumer will make the first purchase of a product, the considerations that will be based will be different from purchases that have been repeatedly done. These considerations can be processed by the consumer from an economic point of view, relationship with others as a result of social relationships, rational cognitive analysis results or more to emotional uncertainty (emotional element). The results of research on the dimensions of reflect decision factors in impulse buying activities in line suggested by Schiffman and Kanuk (2004) which illustrates that at the time of making decisions, all these considerations will be experienced by consumers although the role may vary.

\section{Sudden Decision}

The decision making process begins with a need to strive for. The fulfillment is related to several alternatives so that an evaluation is needed to obtain the best alternative from consumer perception. In the process of comparing these consumers requires information that the number and level of importance depends on the needs of consumers and the situation it faces. Consumer theory goes through all five phases on each purchase. Hence, on regular purchases, consumers sometimes skip or reverse some of those stages. Considerations that arise when a consumer faces a new purchasing situation can be complex. Based on the interview results with one of the sources in this research, turns out that Alfamart customers in Ujungberung, Bandung, rarely take a sudden decision to purchase something, unless if there is a sudden insistence when they see a product that is displayed or the money they have, making their decision to buy an item will surely come by itself without their any of the previous plans. The results of descriptive analysis for the dimensions of sudden decision factors, obtained the minimum value as shown from the following table:

Table 1.4.

The Sudden Decision Factors Affecting Impulse Buying

\begin{tabular}{|l|c|c|c|c|c|c|c|}
\hline \multicolumn{1}{|c|}{ Factors } & $\mathbf{5}$ & $\mathbf{4}$ & $\mathbf{3}$ & $\mathbf{2}$ & $\mathbf{1}$ & Score & Average \\
\hline $\begin{array}{l}\text { When I look at things that } \\
\text { really interest me, I'll buy them } \\
\text { at once, just to fulfill the desire } \\
\text { that comes }\end{array}$ & 37 & 14 & 19 & 18 & 12 & 346 & 3,46 \\
\hline $\begin{array}{l}\text { I will still buy products that I } \\
\text { find interesting though in the } \\
\text { end I will regret }\end{array}$ & 7 & 23 & 33 & 19 & 18 & 282 & 2,82 \\
\hline $\begin{array}{l}\text { I will buy a product, if the } \\
\text { product is very important to me }\end{array}$ & 37 & 39 & 9 & 6 & 9 & 389 & 3,89 \\
\hline Total & & & & $\mathbf{1 0 1 7}$ & $\mathbf{1 0 , 1 7}$ \\
\hline
\end{tabular}

Source: Research Results, 2018

Factor of a sudden decision based on consumer perception is in medium category, or in other words Alfamart consumer in Ujungberung, Bandung, when wanting to shop a product of goods at retail outlet always make first consideration of goods to be purchased rarely make any sudden decisions. This is because a consumer who will search and may also not seek additional information. If the consumer's driven strong and the product needed is within reach, would likely buy it. Otherwise, the consumer will keep it in memory or search some information related the need. Such is the case, what happens in the Ujungberung, Bandung, where consumers sometimes ask other people either friends, or their relatives to recommend a product that they will buy. The results of research on the consumers sudden decision factors in impulse buying activities in line with Schiffman and Kanuk (2004) which illustrates that at the 
time of making decisions, all these considerations will be experienced by consumers although the role will vary.

\section{Automatic Decision}

In taking an automatic decision, consumers rank brand and create purchase intentions. In general, consumer purchase decisions will buy the most preferred brand, but there are two factors that arise between the buying trend and the purchase decision. From the results of interviews with one of the informants in this researchobtained the result that, before making a purchase, usually a consumer pay attention to advertising products, products used by friends, and conversations about the product. The results of descriptive analysis for the last dimension or automatic decision factor obtained the minimum value that can be seen from the following table:

Table 1.5 .

Automatic Decision Factors Affecting Impulse Buying

\begin{tabular}{|l|c|c|c|c|c|c|c|}
\hline \multicolumn{1}{|c|}{ Factors } & $\mathbf{5}$ & $\mathbf{4}$ & $\mathbf{3}$ & $\mathbf{2}$ & $\mathbf{1}$ & Score & Average \\
\hline $\begin{array}{l}\text { The existence of an interesting } \\
\text { product makes me want to try it }\end{array}$ & 17 & 39 & 29 & 6 & 9 & 349 & 3,49 \\
\hline $\begin{array}{l}\text { I cannot suppress my desire to } \\
\text { buy a product when looking at a } \\
\text { product that is interesting }\end{array}$ & 33 & 10 & 29 & 17 & 11 & 337 & 3,37 \\
\hline $\begin{array}{l}\text { The advertised product just like } \\
\text { in television made me want to try }\end{array}$ & 23 & 34 & 29 & 10 & 4 & 362 & 3,62 \\
\hline Total & & & & $\mathbf{1 0 4 8}$ & $\mathbf{1 0 , 4 8}$ \\
\hline
\end{tabular}

Source: Research Results, 2018

The automatic decision factor based on consumer perception is in the high category, or in other words Alfamart consumers in Ujungberung, Bandung, tend to make purchases impulsively when consumers make a visit to retail stores in Ujungberung, Bandung. The existence of a search for information made by consumers of products served in electronic media such as television is one of the biggest factors that cause consumers to purchase impulse buying, in addition to the product with attractive design and make consumers tend to want to try it, though they never tried the product before. This result is in line with research conducted by Park (2006) where impulse buying often appears suddenly, quickly, spontaneously, more emotionally rather than rational, more often regarded as something bad than something good, and consumers tend to feel out of control when buying goods impulsively.

\section{Crosstabulations Analysis}

The result of cross tabulation analysis between age and gender of consumer with impulse buying behavior as follow:

\section{Gender Factor Respondent}

The result of cross tabulation analysis between gender of respondent with tendency to impulse buying based on the following table:

Table 1.6.

Gender Categories With Impulse Buying

\begin{tabular}{|c|c|c|c|c|c|}
\hline \multirow{4}{*}{ Gender } & \multicolumn{4}{|c|}{ Impulse Buying } & \multirow{2}{*}{ Total } \\
\cline { 2 - 6 } & \multirow{3}{*}{ Female } & Count & 18 & 44 & 62 \\
\cline { 2 - 6 } & & Medium & High & \\
\cline { 2 - 6 } & \multirow{2}{*}{ Male } & Count & 21 & 17 & 38 \\
\cline { 2 - 6 } & & $\%$ of Total & $21 \%$ & $17 \%$ & $38 \%$ \\
\cline { 2 - 6 } & Total & Count & $\mathbf{3 9}$ & $\mathbf{6 1}$ & $\mathbf{1 0 0}$ \\
\cline { 2 - 6 } & & \% of Total & $\mathbf{3 1 \%}$ & $\mathbf{6 1 \%}$ & $\mathbf{1 0 0 \%}$ \\
\hline
\end{tabular}

Source: Primary Data, 2018 
Based on the table above, it is known that female consumers have a tendency to make a high impulsive purchase as many as 44 people and female consumers who have tendency to do impulsive giving is as much as 18 people. Furthermore, male consumers who have a tendency to make purchases impulsively as high as 17 people and male consumers who have tendency to do impulsive giving is 21 people.

Based on the results of the above research, it can be concluded that female consumers have higher tendency to make impulsive purchases. In purchases made conventionally, men prioritize the function in shopping. Meanwhile women prioritize social experience, which is associated with identity and emotional involvement (Dittmar, Long and Meek, 2004). The results of this study are in line with Lin and Lin (2005) research results that say if female consumers have the tendency to be more impulsive in shopping than male consumers.

\section{Age Factor Respondent}

The result of cross tabulation analysis between age of respondent with tendency to impulse buying based on the following table:

Table 1.7.

Age Category With Impulse Buying Impulse

\begin{tabular}{|c|c|c|c|c|c|}
\hline \multirow{14}{*}{ Age } & \multicolumn{4}{|c|}{ Impulse Buying } & \multirow{2}{*}{ Total } \\
\hline & Range & & Medium & High & \\
\hline & \multirow{2}{*}{$18-23$} & Count & 9 & 7 & 16 \\
\hline & & $\%$ of Total & $9 \%$ & $7 \%$ & $16 \%$ \\
\hline & \multirow{2}{*}{$24-28$} & Count & 8 & 10 & 18 \\
\hline & & $\%$ of Total & $8 \%$ & $10 \%$ & $18 \%$ \\
\hline & \multirow{2}{*}{$29-34$} & Count & 14 & 25 & 39 \\
\hline & & $\%$ of Total & $14 \%$ & $25 \%$ & $39 \%$ \\
\hline & \multirow{2}{*}{$35-40$} & Count & 5 & 11 & 16 \\
\hline & & $\%$ of Total & $5 \%$ & $11 \%$ & $16 \%$ \\
\hline & Above 40 & Count & 3 & 9 & 12 \\
\hline & & $\%$ of Total & $3 \%$ & $9 \%$ & $12 \%$ \\
\hline & Total & Count & 39 & 61 & 100 \\
\hline & & \% of Total & $39 \%$ & $61 \%$ & $100 \%$ \\
\hline
\end{tabular}

Source: Primary Data, 2018

Based on the table above, it is known that consumers with the age of 18 - 23 years who have a tendency of high impulsive buying behavior as many as 7 people and consumers who have tendency of impulsive buying behavior is as much as 9 people. consumers with the age of 24 28 years who have a tendency of high impulsive purchasing behavior as many as 10 people and consumers who have the tendency of impulsive buying behavior are as many as 8 people. Next, consumers aged 29 - 34 years who have a tendency of high impulsive purchasing behavior as many as 25 people and consumers who have tendency of impulsive buying behavior are as many as 14 people. While, consumers aged 35 - 40 years who have a tendency of high impulsive buying behavior as many as 11 people and consumers who have a tendency of impulsive buying behavior are as many as 5 people. And the last is consumers with age 40 years and over who has a tendency of high impulsive buying behavior as many as 9 people and consumers who have tendency of impulsive buying behavior is as much as 3 people.

Based on the results of the above research, it can be concluded that consumers aged between 29 - 34 years have higher tendency to make impulsive purchase. It can be concluded that the results of this research can be seen from the difference in the behavior of impulse buying by age. The age range 18 - 39 years is the age range included in the early adult development stage. Bandung as one of the student cities with many campuses and dominated by the average 
student is still young, it allows consumers in Retail Alfamart in Ujungberung dominated by students who have a young age, modern lifestyle that causes the tendency to do high enough impulsive purchases. But the results of this research differ from research conducted by Ghani and Farzhan (2010) which states that age has a negative effect on the behavior of impulse buying, meaning that the older a person the lower the tendency for impulsive purchases.

\section{CONCLUSION}

1. Spontaneous Decision Factors affect the customer to perform impulse buying, indicated by a significance value of 0.000 . Hence the first hypothesis (H1) is, the higher the positive emotions of a person the faster the impulse buying decision, can be accepted. The second factor is the reflect decision factor affecting the customer to perform impulse buying, this is indicated by a significance value of 0.000 which is still below 0.05. The second hypothesis (H2) is, the faster the customer response on a product the faster the impulse buying decision can be accepted. The third factor is the Sudden Decision Factor affecting the customer to perform impulse buying, this is indicated by a significance value of 0,000 which is still far below 0.05 . The third hypothesis (H3) is, the more customer interaction with the shopkeeper the faster the impulse buying decision, it is acceptable. The fourth factor is Automatic Decision Factors affecting the customer to perform impulse buying, this is indicated by a significance value of 0.000 which is still far below 0.05 . Hence the fourth hypothesis $(\mathrm{H} 4)$ is, the higher the desire to shop from customers it will automatically the faster impulse buying decision, can be accepted.

2. Spontaneous Decision Factors, Reflect Decision Factors, Sudden Decision Factors and Automatic Decision Factors, have a significant influence together on the desire to make impulse buying. This is shown from the value of $\mathrm{F}_{\text {count }}$ of 47.327 with $\mathrm{F}_{\text {table }}$ of 3.698 and a significance level less than 0.05 , it can be said that the regression model can be used to predict impulse buying.

3. The most influential factor on impulse buying is spontaneous decision with $t$ value equal to 7,806 and valueize coefficient beta 0,743 , then followed by sudden decision factor with $t$ value equal to 4,789 and valueize coefficient beta 0,289 , followed by factor the decision to reflex with the value of $t$ arithmetic of 3.866 and the value of standardize coefficient beta 0.353 and the last is the automatic decision factor with $t$ value of 3.698 and the value of standardize coefficient beta 0.459 .

4. The coefficient of determination is 0.754 or $75.4 \%$. This means that the four factors (spontaneous, reflex, abrupt and automatic) in this study are only able to explain $75.4 \%$ of the variations that occur in the impulse buying variable. While other variations of $100 \%-75.4 \%=24.6 \%$ are explained by other variables not described in this research model.

\section{Reference}

Aaker. David A., V. Kumar, George S. Day. 2004. Marketing Research Seventh Edition. John Wiley \& Sons, Inc. New York, p. 71-73.

Cahyorini \& Rusfian. 2011. The Effect of Packaging Design on Impulsive Buying. Journal of Administrative Science \& Organization, p. 11-21.

Park, Eun Joo. Eun Young Kim. Judith Cardona Forney. 2005. A Structural Model of Fashion-Oriented Impulse Buying Behavior. Journal of Fashion Marketing. Vol. 10, p. 433-446

Park, J., \& Lennon, S. J. 2006. "Psychological and environmental antecedents of Impulse Buying

Rook, D. W. 1987. The Buying Impulse. Journal of Consumer Research.

Rook, D.W. and Fisher, R.J., 1995. Normative influences on impulsive buying behavior. Journal of consumer research, p. 305-313

Schiffman and Lazar Kanuk, 2000, Costumer behaviour, Internasional Edition, Prentice Hall 
Aryani, R., Arifianti, R., Suryanto., \& Purnomo, M. (2018). Factors Affecting Impulse Buying In Alfamart Customers In Ujungberung Sub-District, Bandung. Advances in Social Sciences Research Journal, 5(8) 341-348.

Schiffman, Leon G. Leslie Lazar Kanuk. 2007. Consumer Behavior. Pearson Prentice Hall. America

Utami Christina Whidya. 2006. Manajemen Ritel Strategi dan Implementasi Ritel Modern. Jakarta : Salemba Empat.

2010. Manajemen Ritel: Strategi dan Implementasi Operasional Bisnis Ritel Modern di Indonesia. Jakarta: Salemba Empat. 